\title{
PENGATURAN PEMBATASAN KEBEBASAN PERS DALAM PENYEBARAN INFORMASI DI INDONESIA
}

\author{
I Dewa Gede Agung Mahendra Gautama1 , I Wayan Novy Purwanto² \\ ${ }^{1}$ Kejaksaan Negeri Bangli, E-mail: dejunkgautama@gmail.com \\ 2Fakultas Hukum Universitas Udayana, E-mail: novypurwanto17@gmail.com
}

doi: https://doi.org/10.24843/KS.2020.v08.i10.p12

\begin{abstract}
Abstrak
Tujuan penelitian ini untuk menganalisis pengaturan pembatasan kebebasan pers dalam penyebaran informasi di Indonesia serta akibat hukum tidak pengaturan pembatasan kebebasan pers dalam penyebaran informasi di Indonesia. Metode yang digunakan dalam penelitian terkait pengaturan lembaga penjamin polis pada perusahaan asuransi di Indonesia ini mempergunakan jenis penelitian hukum yuridis normatif dengan pendekatan perundangundangan atau statute approach untuk menganalisis isu hukum pada penelitian ini. Sumber bahan hukum pada penelitian ini terdiri dari bahan hukum primer, sekunder, dan juga tersier. Hasil dari penelitian ini menemukan bahwa belum diaturnya pembatasan kebebasan pers dalam penyebaran informasi di Indonesia secara lebih spesifik dalam Undang-Undang Nomor 40 tahun 1999 tentang Pers. Tidak adanya pengaturan terkait pembatasan kebebasan pers dalam penyebaran informasi di Indonesia mengakibatkan pada lemahnya kualitas karya yang disajikan pers dan akan membuat pers melaksanakan kegiatan jurnalistik yang tidak berdasarkan kaidah yang benar, sehingga karya yang dihasilkan adalah karya jurnalistik tidak berkualitas. Sehingga perlu diperjelas pembatasan kebebasan pers dalam penyebaran informasi di Indonesia melalui Undang-Undang Nomor 40 tahun 1999 tentang Pers.
\end{abstract}

Kata kunci: Pengaturan, Kebebasan Pers, Pers

\begin{abstract}
This study aims to analyze the restrictions on press freedom in the dissemination of information in Indonesia and the legal consequences of not regulating restrictions on press freedom in the dissemination of information in Indonesia. The method used in research related to the regulation of policy insurance institutions in insurance companies in Indonesia uses normative juridical legal research. This study uses a statutory approach or statute approach to analyze legal issues in this study. Sources of legal materials in this study consist of primary legal materials, secondary legal materials, and also tertiary legal materials. The results of this study found that the restrictions on press freedom in the dissemination of information in Indonesia had not been specifically regulated in Law Number 40 of 1999 concerning the Press. The absence of regulations regarding restrictions on press freedom in the dissemination of information in Indonesia results in the weak quality of the work presented by the press and will make the press carry out journalistic activities that are far from correct principles, so that the resulting work is unqualified journalistic work. So it is necessary to clarify the restrictions on press freedom in the dissemination of information in Indonesia through Law Number 40 of 1999 concerning the Press.
\end{abstract}

Keywords: Regulation, press freedom, press

\section{Pendahuluan}

Pers adalah penopang perkembangan demokrasi di Indonesia. Urgensi pers itu tidak dapat dilepaskan dari fungsi yang dilakukan pers yaitu sebagai media hiburan, pendidikan, informasi, social control, serta pelaku ekonomi seperti yang tercantum Pasal 
3 ayat (1) dan (2) Undang-Undang Nomor 40 Tahun 1999 tentang Pers (UU Pers). Dalam melaksanakan seluruh fungsi tersebut terdapat beberapa ciri yang tidak dapat dilepaskan dari pers, antara lain: pers adalah social/public institution (pranata publik atau pranata sosial). Ciri ini berisi makna bahwa walaupun dikenal dengan istilah the fourt estate ataupun the fourt power, namun pers bukanlah substructure dari organisasi yang menyelenggarakan kekuasaan kenegaraan (staatsorganisatie) serta pers hanya bekerja dan memihak terhadap kepentingan publik. Selanjutnya, pers bersifat merdeka (bebas), baik dalam makna independen maupun kebebasan berekspresi pada umumnya misalnya kebebasan memberikan pendapat. ${ }^{1}$

Pers berkontribusi pada kehidupan bermasyarakat serta bernegara memiliki potensi positif dalam pengimplementasian dimensi-dimensi idiil, materiil, serta professional. Perhatian pers tersebut tertuju pada seluruh dimensi tersebut saat dihadapkan dengan kontribusi pada masyarakat tersebut, pemerintah maupun pers. Adapun ciri-ciri Sistem pers nasional yaitu sebagai berikut2:

1. Secara aktif, kreatif, dan positif dalam segi idiil memberikan sumbangan kearah tegaknya kehidupan demokrasi Pancasila

2. Secara aktif, kreatif, dan positif dalam segi materiil, memberi sumbangan ke arah tegaknya demokrasi ekonomi selaras dengan ketentuan Pasal 33 Undang-Undang Dasar 1945, berkaitan tentang pengelolaan usaha penerbitan pers di negeri ini.

3. Secara professional, bernapaskan kebebasan yang mampu dipertanggungjawabkan disertai dukungan keterampilan pada bidang pengabdiannya yang dapat memberikan isi serta nilai pada asas kebebasan yang dapat dipertanggungjawabkan.

Pers memiliki peran yang sangat besar dalam memberikan jaminan dan implementasi demokrasi. Tidak hanya menggerakkan fungsi control, tetapi peran besar pers lainnya dalam hal demokrasi adalah sarana public (komunikator rakyat) pada penyelenggara negara dalam melakukan demokrasi. Dalam demokrasi peran ini semakin penting yang tidak hanya secara nyata hanya dilakukan sekelompok kecil orang namun demokrasi yang makin elitis. ${ }^{3}$ Keberadaan pers sebagai informan pada publik, tidak lepas dari adanya khalayak. Antara media dan khalayak adalah kesatuan yang di analogikan sebagai dua sisi mata uang. ${ }^{4}$ Dua hal tersebut berbeda dan memiliki karakter di tiap sisinya, akan tetapi jika membahas salah satu sisinya pada saat yang bersamaan sisi yang lainnya harus perlu dilakukan pertimbangan. Media ada karena adanya masyarakat selaku penikmat acara tersebut. Namun sebaliknya adanya masyarakat dalam teori tidak mempunyai eksistensi jika tidak adanya media. ${ }^{5}$

${ }^{1}$ Manan, B. (2016). Pers, hukum, dan hak asasi manusia. Dewan Pers. h. 40.

2 Atmadi, T. (1985), Sistem Pers Indonesia, Jakarta, h. 122.

${ }^{3}$ Manan, B. (2013). Kemerdekaan Pers! Mengapa Dan Untuk Apa. Jurnal Dewan Pers Jakarta, Edisi 12, (9). h. 15.

4 Sahputra, D. (2020). Implementasi Hukum Pers di Sumatera Utara. Jurnal Penelitian Hukum De Jure, 20(2), h. 260.

${ }^{5}$ Nasrullah, Rulli, (2019), Teori Dan Riset Khalayak Media, Pertama. Jakarta: Kencana. h. 40 . 
Penjelasan tentang kegiatan yang dilaksanakan oleh pers dalam melengkapi dan melakukan publikasi terhadap sebuah berita lebih difokuskan dalam lingkup pidana yang terlaksana pada proses itu. Ada hal sebagai suatu larangan yang sebenarnya harus dijadikan pembatasan dalam kebebasan pers saat melaksanakan pekerjaannya. Larangan ini bukan berarti untuk memberikan pembatasan yang mengekang bagi pers untuk melakukan inovasi dan menunjukkan kreativitas saat melakukan penyampaian terhadap sebuah berita, akan tetapi sebagai penyaring supaya informasi yang disampaikan bisa dipertanggungjawabkan serta dapat untuk diakses oleh semua kalangan karena penikmat pers tidak hanya orang dewasa. ${ }^{6}$ Namun, hingga saat ini pembatasan kebebasan pers ini belum diatur lebih terperinci dalam UU Pers. Tindakan pers yang dianggap telah melakukan pelanggaran hanya ditegaskan pada Pasal 4 Kode Etik Jurnalistik yang menerangkan bahwa "Wartawan Indonesia tidak membuat berita bohong, fitnah, sadis, dan cabul". Dalam prakteknya pers diwajibkan untuk menjadi pers yang sehat. Maksud dari pers yang sehat yaitu pers yang apabila berisikan hal-hal negatif tentang masyarakat ataupun pemerintah tetap menekankan pada seluruh nilai kepribadian serta kebudayaan meliputi menjunjung kesopanan, proporsional serta mempergunakan bahasa yang tidak menyakiti rasa perseorangan maupun kelompok. ${ }^{7}$

Dari dua kebijakan tersebut sudah memperlihatkan suatu pertentangan norma, di satu sisi UU Pers menjamin kemerdekaan pers sebagai hak asasi warga negara sebagaimana tercantum Pasal 2, namun disisi lain pers dilarang mempublikasikan berita bohong, fitnah, sadis, maupun cabul sebagaimana tercantum pada kode etik jurnalistik. Intinya, kemerdekaan pers yang tidak terbatas merupakan hal yang dalam kenyataan tidak mungkin terjadi, suatu utopia. Pandangan yang menghendaki adanya kemerdekan tanpa batas sudah lama ditinggalkan. Pembatasan yang bersifat preventif, seperti sensor serta braindel, bagaimanapun bertentangan dengan prinsip bebas. ${ }^{8}$ Dalam penjelasan UU Pers, kemerdekaan pers dijamin sebagai hak asasi manusia memiliki makna bahwa pers terbebas pada kegiatan pencegahan, pelarangan, maupun penekanan sehingga hak yang dimiliki masyarakat untuk mendapatkan informasi terjamin. Kemerdekaan pers merupakan kemerdekaan yang diikuti rasa sadar mengenai urgensi dari tegaknya supremasi hukum yang dilaksanakan oleh pengadilan serta pertanggungjawaban profesi yang dituliskan pada Kode Etik Jurnalistik dan sesuai dengan hati nurani insan pers.

Namun makna kemerdekaan pers dalam UU Pers sering disalah artikan dan pers seringkali dinilai terlalu berlebihan bahkan sudah keluar dari etika jurnalistik yang ada. Hal inilah yang kemudian memunculkan terjadinya tindak pidana pers atau delik

${ }^{6}$ Maqhfiroh, F. Y. (2019). Pertanggungjawaban Pidana Media Pers Terkait Penayangan Pornoaksi melalui Media Televisi. Mimbar Keadilan, 12(1), 278214. h. 45.

7 Sadono, Bambang, (1993), Penyelesaian Delik Pers Secara Politis, Jakarta: Pustaka Sinar Harapan, h. 19.

8 Adji, Oemar Seno, (1973), Penyelesaian Delik Pers Secara Politis, Jakarta: Pustaka Sinar Harapan, h. 45 
pers. Padahal sesuai penjelasan di dalam UU Pers ditegaskan pers nasional memiliki peran yang penting dalam melengkapi hak-hak masyarakat untuk mendapatkan informasi serta melakukan pengembangan terhadap pendapat umum, melalui penyampaian informasi yang benar, tepat, dan akurat. Dengan demikian akan memberikan dorongan dilakukan penegakan keadilan serta kebenaran, dan diwujudkannya supremasi hukum dalam upaya mencapai masyarakat yang tertib serta juga pers nasional saat melakukan penyiaran informasi, tidak melakukan penghakiman ataupun merancang kesimpulan dari hal-hal bersalah yang dilakukan seseorang, terutama berkaitan dengan permasalahan yang sedang dalam proses peradilan dan mampu mengakomodir keperluan seluruh pihak yang berkaitan dengan informasi itu. ${ }^{9}$

Pers atau media massa adalah salah satu sarana untuk melakukan komunikasi massa, hal tersebut dikarenakan media massa dapat mencapai pasar yang lebih luas serta terlampau banyak, anonim, heterogen, dan pesannya memiliki sifat yang abstrak serta terpancar. Media massa juga pada kajian komunikasi massa tidak jarang dipahami sebagai perangkat yang diorganisir dalam upaya melakukan komunikasi yang terbuka serta pada situasi yang memiliki jarak pada masyarakat luas pada waktu yang singkat. ${ }^{10}$ Hingga saat ini UU Pers telah berjalan selama dua puluh tahun, namun belum sekalipun undang-undang ini di lakukan revisi. Tidak adanya pembatasan makna dari kemerdekaan pers ini secara khusus yang diatur dalam peraturan perundangan menimbulkan kekaburan norma yang tentu saja berpengaruh pada ketidakpastian hukum. Kekaburan norma yang terjadi mengenai kemerdekaan pers ini berimplikasi pada penyalahgunaan kewenangan yang diberikan kepada pers. Untuk itu penting kiranya dilakukan penambahan poin pembatasan kebebasan pers untuk menanggulangi menyebarnya berita-berita yang membuat banyak pihak terprovokasi dan hal-hal negatif lainnya.

Dengan demikian, penelitian ini akan membahas beberapa hal diantaranya pertama, bagaimanakah pengaturan pembatasan kebebasan pers dalam penyebaran informasi di indonesia? kedua, bagaimanakah akibat hukum tidak diaturnya pembatasan kebebasan pers dalam penyebaran informasi di indonesia?

Penelitian ini adalah karya ilmiah asli yang memiliki harapan untuk dapat berkontribusi dan berperan terhadap penambahan ataupun pengembangan ilmu pengetahuan. Beberapa studi terdahulu yang telah mengkaji mengenai pers diantaranya pertama, ditemukan pada Jurnal Penelitian Hukum De Jure Universitas Medan Area berjudul Implementasi Hukum Pers di Sumatera Utara yang menjelaskan tentang perkembangan hukum pers nasional dan implementasi hukum pers di Sumatera Utara. Kedua, ditemukan pada Jurnal Ilmu Hukum Ajudikasi Universitas

${ }^{9}$ Afdjani, Hadiono, (2015), Ilmu Komunikasi, Banten: Indigo Media, h. 152.

10 Ibid. 
Serang Raya Perlindungan Hukum Terhadap Intervensi Pemberitaan dalam Kerangka Kemerdekaan Pers Nasional yang menjelaskan terkait perlindungan hukum pers mengenai peran pemerintah dan insan pers nasional dalam menjaga kemerdekaan pers nasional dalam kerangka hukum positif serta hukum pers. Ketiga yaitu Jurnal Magister Hukum Udayana Universitas Udayana berjudul Implikasi Uji Kompetensi Terhadap Kesadaran Hukum Pers Wartawan Media Cetak di Kota Denpasar yang menjelaskan mengenai pengaturan mengenai uji kompetensi wartawan dalam hukum pers dan implikasi uji kompetensi terhadap kesadaran hukum pers wartawan media cetak di kota Denpasar.

Penelitian ini memiliki tujuan untuk melakukan analisis pengaturan pembatasan kebebasan pers dalam penyebaran informasi di Indonesia serta akibat hukum tidak diaturnya pembatasan kebebasan pers dalam penyebaran informasi di Indonesia

\section{Metode Penelitian}

Metode penelitian ini menggunakan jenis penelitian hukum yuridis normatif. Penelitian yuridis normatif memiliki arti suatu penelitian yang berfokus terhadap analisis bahan hukum berupa segala jenis peraturan yang berlaku di Indonesia sebagai bahan acuan utama dalam penelitian tersebut. ${ }^{11}$ Suatu penelitian hukum yuridis normatif dapat pula dikatakan sebagai suatu prosedur penelitian yang menggunakan logika ilmu hukum dari sudut pandang normatif untuk menemukan kebenaran, hal tersebut kemudian mampu menjelaskan pengaturan dari lembaga penjamin polis bagi perusahaan asuransi di Indonesia. ${ }^{12}$ Pendekatan dalam menganalisis permasalahan ini adalah statute approach (pendekatan peraturan perundang-undangan) yaitu penelitian yang berfokus pada pengkajian peraturan perundang-undangan terkait dengan isu hukum dalam penelitian ini. Adapun sumber bahan hukum penelitian ini meliputi bahan hukum primer, sekunder, dan juga tersier. Penelitian ini memiliki sifat deskriptif analisis yaitu memberikan gambaran terhadap permasalahan yang dibahas penelitian ini serta melakukan analisis terhadap peraturan hukum terkait untuk memberikan jawab atas permasalahan yang dirumuskan.

\section{Hasil Dan Pembahasan}

\subsection{Pengaturan Pembatasan Kebebasan Pers dalam Penyebaran Informasi di Indonesia}

Kebebasan pers dijamin dan dilindungi secara tegas dalam UU Pers. Dapat dilihat dari banyaknya pasal-pasal dalam UU Pers yang secara eksplisit menjamin kebebasan/kemerdekaan pers. Beberapa pasal penting itu adalah sebagai berikut, pertama Pasal 2 yang pada intinya menjelaskan kemerdekaan pers yaitu perwujudan kedaulatan dengan asas prinsip-prinsip demokrasi, keadilan, serta supremasi hukum, kedua Pasal 4 mengatur bahwa kemerdekaan pers dijamin sebagai hak asasi warga negara. Dari kedua pasal tersebut telah memberikan wewenang yang besar bagi pers.

11 Soekanto, S. (2010). Pengantar Penelitian Hukum. Jakarta : UII Press, h. 201.

12 Ibrahim, J. (2011). Teori dan Metodologi Penelitian Hukum Normatif. Malang : Bayu

Media, h. 57 
Peraturan mengenai kemerdekaan pers seharusnya memberikan keuntungan bagi masyarakat karena bisa mengamati serta memahami bagaimana kinerja pemerintahan. Lain dengan saat masa pemerintahan orde baru, yang segala dilakukan pers terdapat campur tangan pemerintah yang mewajibkan pers hanya memberikan berita sisi positif dari pemerintahan. ${ }^{13}$

Pers memiliki kualitas yang dapat dikategorikan dalam tiga kelompok besar. Kelompok besar tersebut yaitu kelompok pers berkualitas (quality newspaper), kelompok pers populer (popular newspaper), dan kelompok pers kuning (yellow newspaper). ${ }^{14}$

1. Pers Berkualitas

Pers berkualitas dipergunakan secara baik serta tepat berdasarkan konseptual juga professional, meskipun intinya tetap berorientasi pada hal-hal yang bersifat komersial. Pers berkualitas selalu mengedepankan pendekatan rasional institusional dan serius, untuk itu pers berkualitas ini memberikan hasil jurnalistik yang moralis, etis, dan intelektual. Pers berkualitas menjauhi pola pembuatan berita yang memiliki sifat emosional yang tidak terarah, serta lebih menggunakan materi ulasan, laporan, dan tulisan yang berat ataupun memiliki bobot atau nilai. Seluruh informasi, fakta serta data dilihat berdasarkan aturan, pandangan, norma, etika dan kebijakan yang baku dan keamanannya telah dijamin bagi keperluan serta keberlangsungan tingkat majunya perusahaan. Biasanya pers berkualitas disajikan kepada masyarakat kelas menengah atas.

2. Pers Populer

Pers populer mempunyai pola penyajian berita yang mengikuti perkembangan keinginan masyarakat. Sajian jurnalismenya, sederhana, dapat berubah, enak dipandang, mudah dibaca, diperindah dengan taburan warna serta yang paling penting mampu melakukan kompromi dengan keinginan pasar. Metode dalam pers jenis ini lebih memilih metode penyajian serta pendekatan yang kurang etis, emosional (bombastis), serta kadang bisa dikatakan sadis. Kategori pers ini menyenangi penggunaan kata ataupun istilah yang saat ini terkenal di lingkup masyarakat. Pers populer memiliki tujuan untuk menginformasikan dan memberikan rekreasi (hiburan), dikarenakan cara penyajiannya yang ringan. Dibanding dengan pers berkualitas yang sangat mengacu pada arah kebijakan perusahaan serta redaksi, pers jenis ini mampu melakukan perubahan terhadap segalanya demi memenuhi kepuasan masyarakat sebagai sasaran penikmat pers populer.

3. Pers Kuning

Pers kuning merupakan tindakan jurnalisme yang melakukan pengaburan makna. Sejumlah pihak memberikan makna terhadap praktik jurnalisme pers kuning seperti itu. Terdapat pula yang menyebutkan jika jurnalisme kuning bukan pelaksanaan jurnalistik, hal ini dikarenakan, tidak memperhatikan etika serta isinya yang jauh dari realita yang sebenarnya. Sarat akan sensasi, padahal tidak sensasional fakta yang ada. Sarat akan drama, yang pada kenyataannya tidak

13 Tebba, Sudirman, (2005), Jurnalistik Baru, Ciputat: Kalam Indonesia, h. 48.

14 Sumadiria, Haris, (), Hukum dan Etika Media Massa, Panduan Pers, Penyiaran, dan Media Siber, Cetakan ke-1, Bandung: Simbiosa Rekatama, h. 79. 
sedramatis kejadian yang ada. Dilakukan pengaburan makna sedemikian rupa dengan penggunaan kata dan kalimat cabul dan vulgar, bahkan kadang terkesan sadis, khususnya berita mengenai pembunuhan, seks, maupun korban pemerkosaan, di ikuti dengan foto korban yang jelas serta apa adanya, seolah tidak memiliki rasa empati sedikitpun. Beritanya sering kali tidak mampu dipertanggungjawabkan dikarenakan tidak jelasnya sumber ataupun berasal dari narasumber yang tidak kapabel. ${ }^{15}$ Dalam sisi komunikasi, penyebaran berita hasil dari praktik pers kuning merupakan bentuk komunikasi yang tidak tulus, keluar dari koridor etis, serta tentu saja bertendensi negatif. Pada banyak studi, segala tingkah laku buruk yang terjadi di masyarakat tidak sedikit dikarenakan oleh imitasi serta terpengaruh dari segala yang di baca dan lihat pada media massa.

Semenjak era reformasi bergulir, pers mampu merasakan kebebasannya. Angin segar yang menerpa dunia pers Indonesia di samping memberikan nilai positif yang mana pers bisa melakukan fungsinya yaitu control dan penyebarluasan berita, juga sering memiliki dampak yang negatif (negative spread), contohnya terjadi eksploitasi serta manipulasi data dan berita, pemberitaan berkaitan dengan pornografi baik dalam bentuk tulisan maupun gambar, ataupun semacamnya. ${ }^{16}$ Kondisi tersebut terjadi dikarenakan di samping ada pers yang menjadikan segi sensasi dangkal sebagai hal yang utama dari pada urgensi dari peristiwa yang diliput. Hal ini yang menyebabkan tidak jarang pers meliput berita yang menyebabkan kerugian terhadap orang, baik perorangan ataupun kelompok, dan juga pers lebih menjadikan segi komersial sebagai suatu hal yang utama dari pada kualitas suatu berita bahkan lebih jauh lagi telah mengkhusus pada bisnis semata yang kemudian menimbulkan terjadinya penyimpangan-penyimpangan terhadap kode etik pers untuk kepentingan tertentu. ${ }^{17}$

Kode Etik Jurnalistik mengikat dalam bentuk aturan segala kegiatan atau aktivitas dari seluruh jurnalis di Indonesia. Namun, karena Kode Etik Jurnalistik tidak mempunyai ketentuan pidana maka dari itu banyak jurnalis yang tidak mengindahkan kode etik itu. Ketentuan pidana menjadi sulit diterapkan karena adanya ketentuan yang berbenturan dalam penerapannya. Seno Adji dalam Bambang Sadono merumuskan kawasan delik yang dapat diciptakan dalam hukum pidana, yang dikatakan sebagai pembatasan kebebasan pers, untuk melakukan pencegahan agar tidak adanya penyalahgunaan kebebasan itu (abuse of liberty). Selanjutnya Seno Adji mengemukakan secara konkret kawasan pembatasan itu, meliputi18:

15 Malik, A. (2017). Jurnalisme Kuning, “Lampu Kuning” Etika Komunikasi Massa, Ajudikasi: Jurnal Ilmu Hukum, 1(2), h. 10.

${ }^{16}$ Idri, I. (2012). PERS DALAM WACANA HUKUM (Kajian tentang Kebebasan Tanggungjawab, dan Deviasi Pers dalam Perspektif Hukum Islam dan Hukum Positif di Indonesia). Al-ihkam: Jurnal Hukum dan Pranata Social, 5(2), h. 224.

${ }^{17} \mathrm{Ibid}$, hal. 225.

${ }^{18}$ Sadono, Bambang, Op.cit. h. 61. 
a. Delik Terhadap Keamanan Negara dan Ketertiban Umum (National Security and Public Order) terdiri dari Pasal 112 dan 113 KUHP dan Pasal 154, Pasal 155, Pasal 156, Pasal 157, dan Pasal 207.

b. Delik Penghinaan, yang terkenal sebagai (Haatzaai Artikelen) meliputi Pasal 310 dan 315 KUHP.

c. Delik Agama (Godslatering), meliputi Pasal 156 dan Pasal 156a KUHP.

d. Delik Terhadap Kesusilaan atau Delik Pornografi meliputi Pasal 281, Pasal 282, dan Pasal 283 KUHP

e. Delik Penyiaran Kabar Bohong, sebelumnya pada Pasak 171 KUHP selanjutnya dihapus dengan Undang-Undang Nomor 1 Tahun 1946 dan menggantinya dengan Pasal 14 dan 15.

Pada UU Pers yang membahas juga mengenai ketentuan pidana, tidak memuat sama sekali syarat-syarat sebagaimana yang disebutkan diatas, sebagai persyaratan untuk pemberlakuan Undang-Undang Pidana Khusus. UU Pers tidak menyebutkan pembagian pelanggaran maupun kejahatan. KUHP Sebagai induk dari aturan pidana yang berlaku di Indonesia mengikat aturan-aturan pidana yang lain, salah satunya adalah UU Pers. Agar dapat berlaku sebagai suatu aturan khusus, untuk itu UU Pers juga wajib melengkapi kualifikasi delik yang diatur pada KUHP, yaitu adanya pelanggaran dan kejahatan. Apabila tidak disebutkan maka tidak ada aturan khususnya. Hal ini menandakan UU Pers tidak dapat dikatakan sebagai lex specialist dari pasal pada KUHP yang mengatur mengenai tindak pidana pers.

Jika ditelusuri lebih jauh UU Pers hanya mengatur dalam ruang lingkup hak dan kewajiban pers. Bila pihak pers melakukan tindak pidana umum yang diatur dalam KUHP, maka penegak hukum dalam hal ini tentu tidak bisa menggunakan UU Pers, namun tetap menggunakan KUHP, karena UU Pers bukan merupakan kekhususan (lex specialist) dari KUHP itu sendiri. Sebagaimana Pasal 103 KUHP mengatur bahwa segala ketentuan dalam Bab I sampai dengan Bab VIII KUHP juga berlaku bagi segala perbuatan yang oleh ketentuan perundang-undangan lainnya diancam dengan pidana terkecuali jika oleh undang-undang ditentukan berbeda. UU Pers tidak membagi pelanggaran maupun kejahatan seperti yang ada didalam KUHP, dengan demikian UU Pers tidak dilihat sebagai aturan pidana yang bersifat khusus karena tidak sesuai dengan ketentuan induk KUHP Pasal 103. Terlebih lagi UU Pers telah berlaku selama hampir 21 tahun yang belum dilakukan revisi sekalipun, padahal UU Pers sudah tidak relevan lagi dipergunakan saat ini.

\subsection{Akibat Hukum Tidak diaturnya pembatasan kebebasan pers dalam penyebaran informasi di Indonesia.}

Segala penyimpangan pers dalam KUHP sebagai hukum positif bisa dikategorikan sebagai kejahatan kesusilaan yang terdiri dari tiga hal, yaitu ${ }^{19}$ pertama, menyebarkan,

\footnotetext{
19 Lumintang, (1990), Delik-Delik Khusus, Bandung: Mandar Maju, h. 40-41.
} 
menunjukkan, ataupun menempel secara terbuka tulisan yang substansinya berupa benda ataupun gambar yang bersifat melanggar kesusilaan. Kedua, membuat, mempunyai, mengeluarkan, atau memasukkan dalam persediaan tulisan yang substansinya berupa benda atau gambar yang bersifat melanggar kesusilaan untuk disebarkan, ditunjukkan ataupun ditempel secara terbuka. Ketiga, tanpa diminta, memberikan penawaran ataupun menyertakan sebagai dapat diperoleh tulisan yang substansinya berupa benda atau gambar yang bersifat melanggar kesusilaan baik dilaksanakan terbuka ataupun dilaksanakan dengan metode menyebarkan suatu tulisan.

Dengan tidak diaturnya pembatasan terhadap kebebasan pers praktik pers yang menyimpang semakin berkembang kian pesat di Indonesia. Tindakan-tindakan seperti itu berkembang dengan pesat di berbagai media ataupun situs berita online. Lemahnya aturan serta mudahnya pembuatan media berbasis online, di ikuti dengan keinginan mendapat sebanyak-banyaknya klick, visit, dan view dari pembaca agar traffic-nya terus terjadi peningkatan sebagai upaya memperoleh iklan, membuat media berita online berlomba menampilkan pemberitaan yang bombastis yang arahnya pada praktik pers yang berlaku menyimpang. ${ }^{20}$

Dalam kondisi tanpa adanya pembatasan kebebasan pers, yang ada merupakan pers menjadi lebih mengarah pada main hakim sendiri, yang karena terpengaruh dari yang ditimbulkan masyarakat tanpa tahu berita yang pasti mengikuti untuk main hakim sendiri. Pemahaman dan pengetahuan jurnalis Indonesia terhadap kode etik jurnalistik belum memadai. Kedua, tidak adanya prasyarat yang ketat agar dapat menjadi wartawan, tanpa adanya syarat apapun menyebabkan kualitas dari wartawan itu sendiri dan berpengaruh pada pengesampingan terhadap kode etik jurnalistik. ${ }^{21}$

Pers memiliki sifat dan karakter yang dapat mencapai massa dengan jumlah yang luas dan besar, media massa sudah memberi resiko bagi kehidupan budaya dan politik kontemporer saat ini. Dalam segi politik, elemen penting dalam proses demokratisasi adalah media massa, hal ini dikarenakan media massa memberi tempat serta saluran bagi debat publik, membuat calon pemimpin politik diketahui oleh banyak khalayak serta memiliki peran pula dalam penyebarluasan segala pendapat maupun informasi. Sedangkan dalam segi budaya, media massa sudah menjadi tolok ukur utama dalam penentuan pengertian-pengertian tentang suatu permasalahan, serta media massa melakukan pemberian bayangan mengenai realitas sosial. Perhatian utama masyarakat dalam hal memperoleh hiburan serta memberikan lingkungan budaya bersama bagi setiap orang juga tertuju pada media massa. Termasuk juga kontribusi dalam hal ekonomi, terus terjadi peningkatan bersama dengan bertambah tingginya

${ }^{20}$ Malik, A. Op.cit, h. 9.

21 Sukardi, Wina Armada, (2007), Close Up Seperempat Abad Pelaksanaan Kode Etik Jurnalistik, Jakarta: Dewan Pers, h. 59-60 
perkembangan industri media, konsolidasi kekuatan media massa pada masyarakat, serta diversifikasi media massa. ${ }^{22}$

Media massa berpengaruh terhadap dinamika politik, sosial, serta budaya, juga perubahan pada tingkah laku sosial masyarakat. Terjadinya pers kuning terhadap beberapa media massa baik elektronik, cetak, ataupun yang memiliki sifat online, juga berpengaruh besar terhadap sikap maupun tingkah laku masyarakat. Pengaruh ataupun efek komunikasi massa ataupun disebabkan oleh media massa merupakan adanya sikap, emosi, pengetahuan ataupun perilaku tiap-tiap orang ataupun seseorang yang melakukan konsumsi yang berubah terhadap media itu sebagai hasil pemaparan media massa yang dilaksanakan secara keberlanjutan. ${ }^{23}$

Kemerdekaan yang diberikan undang-undang kepada pers sebenarnya untuk melakukan perwujudan kedaulatan rakyat yang berasas prinsip-prinsip demokrasi, supremasi hukum, serta keadilan, sebagaimana tujuan dari UU Pers, Namun, tanpa adanya pembatasan terhadap kemerdekaan pers tersebut menyebabkan banyaknya penyalahgunaan wewenang yang terjadi. Sanksi yang diberikan Dewan Pers tidak begitu mengikat pers yang terkategori sebagai pers yang berlaku menyimpang. Hal ini tentu saja membahayakan bagi pembaca maupun penonton karena mampu menyebabkan mudahnya masyarakat Indonesia terprovokasi terhadap berita-berita yang belum diketahui faktanya.

Kebebasan pers lebih dimaknai wujud dari kegiatan yang bebas dengan tidak adanya batasan yang mengenyampingkan seluruh nilai etika profesi dan juga pertanggungjawaban sosial oleh pers. Suasana kebebasan seolah bagian dari momen bagi setiap orang untuk masuk dalam industri media, walaupun tanpa di ikuti keahlian berupa persiapan modal, moral, dan juga keahlian dalam bidang jurnalistik. Dengan dalih kebebasan juga mereka melaksanakan kegiatan jurnalistik tanpa memperhatikan apakah kaidah yang dipergunakan benar atau salah, hal ini yang menyebabkan karya yang dihasilkan menjadi suatu karya jurnalistik tidak berkualitas serta minim unsurunsur kebaikan didalamnya, kecuali hiburan yang sengaja dibuat penuh sensasi. ${ }^{24}$

\section{Kesimpulan}

Pengaturan pembatasan kebebasan pers dalam penyebaran informasi di Indonesia belum diatur secara khusus, pengaturan mengenai kemerdekaan pers sebagai hak asasi warga negara tanpa diatur sebatas mana kemerdekaan yang diberikan menjadikan pers berlaku sebebas-bebasnya dan melampaui wewenangnya sebagai lembaga penyebar berita. Kekaburan norma ini tentu akan berakibat pada lemahnya kualitas karya yang disajikan pers dan akan membuat pers melaksanakan kegiatan jurnalistik yang sering

${ }^{22}$ McQuail, Dennis, (2000), McQuail's Mass Communication Theory. New Delhi: Sage

Publications, Ltd.

${ }^{23}$ Straubhaar, J., LaRose, R. dan Davenport R. (2011). Media Now: Understanding Media, Culture and Technology, Thomson-Wadsworth.

${ }^{24}$ Malik, A. Op.cit, h. 2. 
kali tidak mempergunakan kaidah yang benar, hal ini menyebabkan karya yang dihasilkan menjadi suatu karya jurnalistik yang tidak berkualitas serta minim unsurunsur kebaikan, kecuali hiburan yang dibuat penuh sensasi. Untuk itu penting dilakukan pengaturan pembatasan kebebasan pers dalam penyebaran informasi di Indonesia sehingga pers tidak dengan mudah membagikan informasi yang tidak sesuai dengan fakta.

\section{Daftar Pustaka}

Buku

Adji, Oemar Seno, (1973), Penyelesaian Delik Pers Secara Politis, Jakarta: Pustaka Sinar Harapan.

Afdjani, Hadiono, (2015), Ilmu Komunikasi, Banten: Indigo Media.

Atmadi, T. (1985), Sistem Pers Indonesia, Jakarta: Gunung Agung.

Ibrahim, J. (2011). Teori dan Metodologi Penelitian Hukum Normatif. Malang: Bayu Media.

Lumintang, (1990), Delik-Delik Khusus, Bandung: Mandar Maju.

Manan, B. (2016). Pers, hukum, dan hak asasi manusia. Dewan Pers.

McQuail, Dennis, (2000), McQuail's Mass Communication Theory. New Delhi: Sage Publications, Ltd.

Nasrullah, Rulli, (2019), Teori Dan Riset Khalayak Media, Pertama. Jakarta: Kencana.

Sadono, Bambang, (1993), Penyelesaian Delik Pers Secara Politis, Jakarta: Pustaka Sinar Harapan.

Soekanto, S. (2010). Pengantar Penelitian Hukum. Jakarta: UII Press.

Sukardi, Wina Armada, (2007), Close Up Seperempat Abad Pelaksanaan Kode Etik Jurnalistik, Jakarta: Dewan Pers.

Sumadiria, Haris, (), Hukum dan Etika Media Massa, Panduan Pers, Penyiaran, dan Media Siber, Cetakan ke-1, Bandung: Simbiosa Rekatama.

Tebba, Sudirman, (2005), Jurnalistik Baru, Ciputat: Kalam Indonesia.

\section{Jurnal}

Idri, I. (2012). PERS DALAM WACANA HUKUM (Kajian tentang Kebebasan, Tanggungjawab, dan Deviasi Pers dalam Perspektif Hukum Islam dan Hukum Positif di Indonesia). Al-Ihkam: Jurnal Hukum dan Pranata Sosial, 5(2), 223-242.

Malik, A. (2017). Jurnalisme Kuning, 'Lampu Kuning' Etika Komunikasi Massa. Ajudikasi: Jurnal Ilmu Hukum, 1(2).

Manan, B. (2013). Kemerdekaan Pers! Mengapa Dan Untuk Apa. Jurnal Dewan Pers Jakarta, Edisi 12, (9).

Maqhfiroh, F. Y. (2019). Pertanggungjawaban Pidana Media Pers Terkait Penayangan Pornoaksi melalui Media Televisi. Mimbar Keadilan, 12(1), 278214.

Sahputra, D. (2020). Implementasi Hukum Pers di Sumatera Utara. Jurnal Penelitian Hukum De Jure, 20(2), 259-274.

Straubhaar, J., LaRose, R. dan Davenport R. (2011). Media Now: Understanding Media, Culture and Technology, Thomson-Wadsworth.

\section{Perundang-Undangan}

Kitab Undang-Undang Hukum Pidana

Undang-Undang Republik Indonesia Nomor 40 Tahun 1999 tentang Pers (LN No. : 166, TLN No. : 3887 ) 